\title{
Students' Perception of Extracurricular Activities: a Case Study
}

\author{
Anna $\operatorname{Han}^{1}$ and Kyungbin Kwon ${ }^{2 *}$ \\ ${ }^{1}$ Department of Education, Daegu Catholic University, Gyeongsan, Korea \\ ${ }^{2}$ Instructional Systems Technology, Indiana University, Bloomington, U.S.A. \\ Email: kwonkyu@indiana.edu
}

\begin{abstract}
The study introduces a case study of a system managing the extracurricular activities (ECA) of students at the university level. A survey asking how students perceived the ECA system was administered and 2591 students participated. Results revealed that 1) $85 \%$ of the students were aware of the ECA system and showed moderate attitudes towards the system; 2) students perceiving the ECA system as helpful and easy to use expressed that activities discovered through the ECA system were beneficial to their curriculum learning and participation in ECA, and, in turn, to their career development and college life overall.
\end{abstract}

Keywords: Extracurricular activities; co-curricular activities; higher education.

\section{Introduction}

Learning and personal development during college years have been achieved through engagement in both academic and non-academic activities which occur inside and outside the classroom (Astin, 1993; Kuh, Douglas, Lund, \& Ramin-Gyurnek, 1994; Terenzini \& Pascarella, 1991). In this sense, colleges should consider the ineffectiveness of having solely classroom learning and encourage students to devote meaningful time outside the classroom for educationally purposeful activities (Kuh, Kinzie, Schuh, \& Whitt, 2011). Most scholars who study the impact of college life on students agree that what happens outside the classroom can contribute to the valuable outcomes of college (Kuh, 1995). These studies reveal that participation in extracurricular activities such as living in a campus residence, collaboration on research projects, involvement in clubs and organizations, interacting with faculty and peers, and voluntarism have all been positively related to persistence and satisfaction (Astin, 1977; Pascarella, Terenzini, \& Feldman, 2005) and gains in such areas as social competence, confidence, self-esteem, selfawareness, and appreciation for human diversity (Kuh, 1995).

A variety of activities outside the formal curriculum are referred to as extracurricular activities (ECA, hereafter). ECA are found at all levels in school systems in many different forms (Foster, 2007). In particular, ECA designed and operated by universities commonly facilitates the advancement of academic achievements as well as social and emotional enrichment (Joseph, 2009). In general, extracurricular activities are not included as part of the formal curriculum and so colleges do not count them toward academic performance. Therefore students who participate in ECA do not receive grades or credit for it. However, these activities are eventually shown to play an important role in a student's college life and career development. In addition students also learn how to apply the knowledge learned in the classroom to real world scenarios by participating in ECA (Shamsudin, Ismail, Al-Mamun, \& Nordin, 2014).

In general, the assessment of student learning in college has focused only on academic achievement occurring in the classroom, laboratory, studio, and library and has overlooked ECA (Kuh, 1993). However, transcripts and test scores reflect only a part of a student's development rather than their overall improvement (Light, 1990). According to Moffatt (1989), about $40 \%$ of college students have significant educational experience gained through out-of-classroom activities. Besides, participation in ECA can be a more accurate predictor of workplace competence than grades. Many studies have shown that participating in ECA helps students to acquire diverse knowledge and competencies through various out of class activities (Astin, 1984; Bae \& Kim, 2012; Kuh et al., 2011; Pascarella et al., 2005).

As the necessity for extracurricular learning has been emphasized in recent years, Korean universities have recognized the importance of ECA. To continuously cultivate the human resources required by society, universities need to provide college students with meaningful ECA so they can strengthen the 
competencies relevant to their future careers (Moon \& Eum, 2015). To do this universities have expanded the administrative and financial support required to operate and activate various ECA in Korea. However there are still some barriers to overcome such as student's lack of awareness about ECA, a lack of extracurricular programs that satisfy students' needs, and institutional supports to manage comprehensive extracurricular programs (Kim \& Lee, 2016). The reason for this is that students tend to focus on the academic grades needed for their employment and select only activities that impact their credit and career preparation. ECA which students voluntarily participate in are not included in their academic grades, so these lead students away from their interests despite the benefits (Baek \& Jung, 2012). The ECA designed by the universities should be aligned with the student's ability and needs in order to get the desired outcomes (Shamsudin et al., 2014). For positive outcomes from ECA, it is necessary that students not only voluntarily participate in various ECA activities but also that there are college-level efforts to provide students with programs that are beneficial and assist them in managing their performance (Wolf-Wendel, Ward, \& Kinzie, 2009).

Therefore, for quality participation in ECA, a university needs to offer valuable ECA programs at the university level and provide an ECA performance management system. Although many universities have introduced and implemented a variety of information management systems to maintain effective educational services, they are not tailored toward ECA (Yang, 2015). In order for ECA to operate and be managed effectively, a system is needed to support and evaluate students' participation in their extracurricular activities.

In this context, this study introduces a case study of a system that can systematically manage the ECA of students at the university level. This ECA management system designed by the university provides students with information on ECA programs they can participate in, administers program applications and results, evaluates performance, and provides a statistical distribution of ECA records. The actions at the university level for the establishment of the ECA management system have been recently carried out, and research on students' perceptions of the system can provide clearer directions for a systematic approach to extracurricular activities. The case study explores student's perceptions of the ECA system and examined how it predicts a student's participation in curriculum as well as extracurricular activities, career development, and college life. In the following section, we review the research trend regarding ECA and the ECA system introduced in this study.

\section{$2 \quad$ Literature Review}

\subsection{Definition of ECA}

As the term "extra" implies, the extracurricular activities (ECA) are not part of the curriculum or classroom activities that are mandatory and involve a grade or academic credit as a result of the activities (Bartkus, Nemelka, Nemelka, \& Gardner, 2012). In this sense, one critical feature of ECA is that the participation in ECA is optional and according to a student's voluntary interests (Pascarella et al., 2005). ECA include both academic and non-academic activities such as reading clubs, foreign language learning groups, climbing, athletics, dance and so on. Bartkus and his colleagues (2012) suggest that ECA can have either a direct or indirect relation to the curriculum. Direct ECA are closely associated with the student's major or learning curriculum while indirect ECA are not.

Although there is a lack of scholarly definitions for ECA, in a broad sense ECA mean activities that students experience during college life in addition to formal education (Bartkus et al., 2012). Thus this study considers ECA as an umbrella term that includes various voluntary activities that are related directly or indirectly to curriculum but do not involve any formal grades reported in student's transcript. In this sense, ECA include various activities in and out of the university such as participation in special lectures, clubs and group activities, student councils, service activities, awards, contests and competitions, exhibitions, performances, internships, and a variety of experience programs and external activities.

\subsection{Benefits of ECA}

Although the findings of research on the participation in ECA are not conclusive, studies on ECA other 
than athletics have provided consistent results suggesting a positive association between participation in the activities and academic achievement and psychosocial measures (Camp, 1990; Eccles \& Barber, 1999; Marsh, 1992).

According to Kuh (1995), participation in ECA contributes to (a) cognitive complexity (e.g., critical thinking, intellectual flexibility, reflective judgment), (b) knowledge acquisition and application, (c) humanitarianism (e.g., interest in the welfare of others), (d) interpersonal and intrapersonal competence (e.g., self-confidence, self awareness, ability to relate to others), and (e) practical competencies (e.g., decision making, vocational preparation). ECA also enhance a student's persistence and educational attainment (Kuh, 1994; Kuh et al., 1994). In addition, many other studies have shown that ECA improve students' cognitive and academic development and the development of new knowledge and skills (Arip \& Yusof, 2002; Astin, 1993; Kuh, Hu, \& Vesper, 2000; Terenzini, Pascarella, \& Blimling, 1996).

Regarding the academic outcomes of ECA, participation in ECA has been positively associated with academic achievement including better grades and test scores, increased engagement in school, and educational aspirations (Eccles \& Barber, 1999; Huang \& Chang, 2004; Massoni, 2011). It is also supposed that ECA have a positive impact on academic achievement through the reduction of problem behaviors, declining dropout rates, and the integration of learning processes (Ahren, 2010; Bakoban \& Aljarallah, 2015; Hattie, 2008; Hunt, 2005; White \& Gager, 2007).

Participation in ECA has a positive impact on job-related competency development such as interpersonal relationships and leadership. Boone, Kurtz, and Fleenor (1988) suggest that the CEOs of large U.S. industrial corporations had more actively engaged in ECA than did other students during their college years. Rubin, Bommer, and Baldwin (2002) found that business students who participated in ECA showed higher interpersonal skills and suggested "extracurricular involvement is associated with stronger communication, initiative, decision-making, and teamwork skills" (p. 449). Similarly, Rynes, Trank, Lawson, and Ilies (2003) also found that the students who participated in ECA demonstrated the desired leadership and interpersonal skills. Overall ECA have a positive impact on basic skills such as interpersonal skills, teamwork skills, presentation skills, self-direction and project management skills, which can contribute to future employability and career development (Wood, Little, Goldring, \& Jenkins, 2011).

Students can identify their capacities and enhance competencies required for their future careers through ECA (Bartkus et al., 2012). Although students may not get enough practice during classroom activities because of constraints and lack of authentic opportunities for practice, ECA often allow them to apply their knowledge in real situations (Shamsudin et al., 2014).

Through ECA, students are also able to fulfill their personal goals and improve the general skills needed in everyday life. ECA may enhance students' problem solving, analytical and critical thinking skills through co-operative activities and hands-on experiences. ECA are important for enhancing students' academic confidence, social development and their sense of well-being at school and facilitating the development of interpersonal skills and positive social norms (Eccles, Barber, Stone, \& Hunt, 2003; Stuart, Lido, Morgan, Solomon, \& May, 2011). Activities outside class such as club activities, mentoring, etc. promote college life adaptation, satisfaction, and commitment (White \& Gager, 2007).

\subsection{University's ECA Operating Environment and System}

Educational system based on core competencies. D University is a large comprehensive university with more than 14,000 students in South Korea. D University needed a specialized educational system which fits their students' characteristics and reflects the education philosophy of the university which is local and private and founded on Catholic ideals. The university has set up core competencies appropriate to the university's ideals and human resources. It has re-established the curriculum and offered various kinds of extracurricular programs based on the core competencies. In order to facilitate and manage the integrated institutional efforts regarding the core competencies, the university established a system that can integrate and evaluate student achievement in ECA.

The educational system has been developed to evaluate the efforts toward and the achievement of the core competencies through the curriculum and ECA in a multi-dimensional and comprehensive way rather than evaluating students' educational achievements solely by grades (GPA). For this, it emphasizes ECA as being as valuable as the formal curriculum and divides the kinds of ECA into 
subject matter related and non subject matter related activities. The system enables the university to monitor and manage student's activities toward the core competencies by looking at which courses the students take, which extracurricular activities they participate in, and the results they get.

Competency Index. The Competency Index is an index that shows how much a student has put efforts into enhancing their core competencies through their curriculum and participation in ECA, and the level of results the student achieved educationally. The Competency Index consists of a Curricular Index and an Extracurricular Index. The Curricular Index, which is an overall course achievement score, is an index representing academic achievement aligned with the core competency. The Extracurricular Index represents performance in extracurricular activities including various ECA on and off campus that are aligned with the core competency. ECA programs are those sponsored by, and usually held at, the university but are not part of the academic curriculum, such as short and long-term special lectures, club or student association activities, in-school volunteer activities, competitions, journal publications, exhibitions, academic events, performances, internships, camps, diagnostic tests, counseling, official language tests, certification, and various outside activities. Extracurricular program designers assign a competency portion to each program according to the characteristics of the ECA program. As a result, students earn equivalent credits based on ECA activity hours as Table 1 describes.

Table 1. Equivalent credits of ECA

\begin{tabular}{l|l|l}
\hline Activity hours & Equivalent credits & Examples of ECA \\
\hline $1 \mathrm{~h} \sim 2 \mathrm{~h}$ & 0.1 & All sorts of one-time Special Lecture \\
\hline $2 \mathrm{~h} \sim 4 \mathrm{~h}$ & 0.2 & Employment Special Lecture, Diagnostic Check \\
\hline $4 \mathrm{~h} \sim 6 \mathrm{~h}$ & 0.3 & Speaking and Writing Special Lecture, Group Activity \\
\hline $6 \mathrm{~h} \sim 8 \mathrm{~h}$ & 0.4 & Voluntary Service, Speaking Skill Contest Conference, Mentoring \\
\hline $8 \mathrm{~h} \sim 10 \mathrm{~h}$ & 0.5 & Voluntary Services related to the Major \\
\hline $10 \mathrm{~h} \sim 20 \mathrm{~h}$ & 1 & Remedial Program, School Academic Seminar \\
\hline $20 \sim 30 \mathrm{~h}$ & 1.5 & Club Activities, National Exhibition \\
\hline $30 \mathrm{~h} \sim 40 \mathrm{~h}$ & 2 & Student Research Community, National Skill Qualification Certificate \\
\hline $40 \mathrm{~h} \sim 50 \mathrm{~h}$ & 2.5 & Enrolled Student Expended Foreign Dispatch Program \\
\hline $50 \mathrm{~h}$ or higher & 3 & $\begin{array}{l}\text { Major courses Foreign Experience, Domestic and Foreign Internship, } \\
\text { Newspaper Journalist }\end{array}$ \\
\hline
\end{tabular}

ECA System. The university has developed an information system that manages all ECA programs provided by university in an integrated and systematic way so that one can open an ECA program, send a notification, and accept an application as well as report participation, completion and performance of ECA through the ECA system. Students can easily check their achievement in their curriculum and ECA, also their student counseling, career guidance, and student resume program through the system. They are also able to build their portfolio by collecting activities they have done and use it as a 'learning history certificate'. In addition, a scholarship element has recently been added to the ECA system that encourages students to participate in more ECA programs related to their major or academic needs.

\subsection{Purpose}

The purpose of this study has been to examine students' perceptions of the ECA system and its impact on their academic activities as well as participation in ECA, career development, and college life. Researchers hypothesized that the perception of the ECA system would have positive relationship to curriculum learning, participation in ECA, career development, and college life. The following research questions were addressed:

1) How do students perceive the helpfulness and usefulness of the ECA system?

2) How is the perception related to a student's academic and non-academic activities? 


\section{$3 \quad$ Method}

\subsection{Participants}

This survey was conducted in cooperation with the departments of D University in Fall 2015. A total of 2591 students responded to the survey (a response rate of 20\%). Forty-four percent of the participants $(\mathrm{n}=1158)$ were female and $55 \%$ were male $(\mathrm{n}=1433)$. The participants were evenly distributed across the years from freshman to seniors (year 1: 25\%, year 2: 27\%, year 3: 24\%, year 4: 23\%, other: 1\%).

\subsection{Instrument}

In order to measure the students' perceptions of the ECA system, researchers collected survey responses from the university students. The survey evaluated the helpfulness and usability of the ECA system with questions such as: I am satisfied with the ECA system in general; The ECA system is beneficial to me; The ECA system is easy to use; I am fully informed on how to use the ECA system. The survey also measured the perceived impacts of the ECA system on their participation in their curriculum and ECA, career development and college life. Regarding the curriculum and ECA, questions regarding motivation as well as self-regulation aspects were asked. In regards to career development, questions on how the ECA system supported student's career preparation were asked. In addition, self-efficacy and confidence in regards to college life were evaluated. A student's demographic information such as major, academic year, and gender was collected. The survey consisted of twenty-seven questions that had been developed by the university research institute and reviewed by experts to ensure face validity. All responses were measured with a 5-point Likert scale that ranged from 1 (strongly disagree) to 5 (strongly agree). Internal reliabilities regarding the constructs were measured (see results).

\subsection{Data Analysis}

First, the internal reliability of the survey items was tested based on the constructs. Next, an analysis of the correlation between the constructs was carried out to see the overall relationships. In order to test a model describing relations of the constructs, researchers conducted multiple regression analyses. The helpfulness and usability of the ECA system were entered in the regression analysis to see whether they predicted the curriculum and ECA. In the following analysis, the curriculum and ECA were entered in the regression analysis to see whether they predicted the career development and college life.

\section{$4 \quad$ Results}

The results of this study will be described in three areas: (a) descriptive analysis of participants regarding the ECA system, (b) relations between constructs related to the ECA system, and (c) predictive models regarding the effects of the ECA system on career development and college life.

\subsection{Descriptive Statistics of Constructs}

First, researchers checked whether the participants were aware of the ECA system. About $85 \%$ of the participants $(\mathrm{n}=2208)$ were aware of it while $15 \%$ were not $(\mathrm{n}=381$, two missing). Because the main purpose of this study was to examine student's perceptions and the effects of the ECA system, the participants who were not aware of it were excluded from the study.

Results regarding the constructs measured by the survey reveal that all the constructs were quite reliable ( $\alpha$ ranged between .75 and .93). The averages for the constructs ranged between 3.06 and 3.37 out of 5, which suggests that students' perceptions of the ECA system as well as other constructs were moderate (see Table 2).

\subsection{Relations among Constructs}

A Pearson correlation analysis was employed to examine the relations among constructs. Overall all 
constructs showed strong positive correlations among each other ( $\mathrm{r}$ ranged between .59 and .79). The results reveal that students' perceptions regarding the helpfulness and usability of the ECA system was positively related to the other constructs such as curriculum, participation in ECA, career development, and college life (see Table 2). As the constructs were highly correlated, multicollinearity of variables was tested in the following analysis.

\subsection{Predictive Models Regarding the Effects of ECA System}

Stepwise regression analyses were employed to examine how well students' perception regarding the helpfulness and usability of the ECA system would predict the benefits of the ECA system on the student's curriculum as well as on their participation in ECA (see Table 3). Helpfulness and usability of the ECA system together accounted for approximately $57 \%$ of the variance in curriculum activities (R2 $=.57), \mathrm{F}(2,2132)=1415, \mathrm{p}<.001$. Both helpfulness $(\beta=.59)$ and usability $(\beta=.21)$ of the ECA system were significant predictors of curriculum activities.

Table 2. Summary statistics and pearson correlations coefficients of constructs

\begin{tabular}{lllllll}
\hline & 1 & 2 & 3 & 4 & 5 & 6 \\
\hline 1. Helpfulness & - & & & & & \\
\hline 2. Usability & $.70^{* *}$ & - & & & & \\
\hline 3. Curriculum & $.74^{* *}$ & $.63^{* *}$ & - & & & \\
\hline 4. Non-Curriculum & $.74^{* *}$ & $.62^{* *}$ & $.79^{* *}$ & - & & \\
\hline 5. Career & $.69^{* *}$ & $.59^{* *}$ & $.78^{* *}$ & $.79^{* *}$ & - & \\
\hline 6. College life & $.68^{* *}$ & $.60^{* *}$ & $.78^{* *}$ & $.75^{* *}$ & $.79^{* *}$ & - \\
\hline $\mathrm{N}$ & 2195 & 2189 & 2165 & 2140 & 2155 & 2162 \\
\hline Mean & 3.32 & 3.37 & 3.12 & 3.35 & 3.21 & 3.06 \\
(SD) & $.823)$ & $.719)$ & $(.85)$ & $(.856)$ & $(.868)$ & $(.891)$ \\
\hline Cronbach $\alpha$ & .84 & .75 & .93 & .92 & .91 & .87 \\
\hline & & & & & &
\end{tabular}

** $\mathrm{p}<.01$

Table 3. Summary of regression analysis

\begin{tabular}{|c|c|c|c|c|c|c|}
\hline Dependent Variables & Variables Entered & $\mathrm{R} 2$ & $\mathrm{df}$ & $\mathrm{F}$ & $\beta$ & VIF \\
\hline \multirow[t]{3}{*}{ Curriculum } & & .57 & 2,2132 & $1415^{* * *}$ & & \\
\hline & Helpfulness & & & & $.59 * * *$ & 1.96 \\
\hline & Usability & & & & $.21^{* * *}$ & 1.96 \\
\hline \multirow[t]{3}{*}{ ECA } & & .57 & 2,2108 & $1420^{* * *}$ & & \\
\hline & Helpfulness & & & & $.60 * * *$ & 1.98 \\
\hline & Usability & & & & $.20^{* * *}$ & 1.98 \\
\hline \multirow[t]{3}{*}{ Career } & & .69 & 2,2117 & $2345^{* * *}$ & & \\
\hline & ECA & & & & $.48^{* * *}$ & 2.69 \\
\hline & Curriculum & & & & $.40^{* * *}$ & 2.69 \\
\hline \multirow[t]{3}{*}{ College Life } & & .66 & 2,2124 & $2018^{* * *}$ & & \\
\hline & Curriculum & & & & $.51^{* * *}$ & 2.69 \\
\hline & $\mathrm{ECA}$ & & & & $.35^{* * *}$ & 2.69 \\
\hline
\end{tabular}

Note. All betas are standardized.

$* * * \mathrm{p}<.001$

Regarding participation in ECA, helpfulness and usability of the ECA system together accounted for approximately $57 \%$ of the variance in participation in ECA $(\mathrm{R} 2=.57), \mathrm{F}(2,2108)=1420, \mathrm{p}<.001$. Both helpfulness $(\beta=.60)$ and usability $(\beta=.20)$ of the ECA system were significant predictors of participation in ECA. 
Stepwise regression analyses were also employed to examine how well the curriculum and participation in ECA would predict participation in career development and college life. Curriculum activities and ECA together accounted approximately $69 \%$ of the variance in career development (R2 $=.69), \mathrm{F}(2,2117)=2345, \mathrm{p}<.001$. Both curriculum $(\beta=.48)$ and $\operatorname{ECA}(\beta=.40)$ activities were significant predictors of participation in career development.

Regarding college life, curriculum and ECA together accounted for approximately $66 \%$ of the variance in college life $(\mathrm{R} 2=.66), \mathrm{F}(2,2124)=2018, \mathrm{p}<.001$. Both curriculum $(\beta=.51)$ and ECA $(\beta=.35)$ activities were significant predictors of participation in college life.

Multicollinearity among the independent variables was checked and variance inflation factors (VIF) did not indicate any concerns (all VIFs were less than 2.7).

\section{Discussion}

The purpose of this study is to introduce the case study of a system that systematically manages the ECA of students at the university level. It analysed how students perceived the helpfulness and usability of the ECA system and how their perceptions related to their curriculum activities and their participation in ECA, career development and college life.

To this end, we first looked at students' perceptions of the ECA system. As a result, $85 \%$ of the students were aware of the ECA system, and their perceptions and attitudes toward the extracurricular programs and the ECA system were moderate at 3.06-3.37. These results are consistent with previous studies showing that students have low recognition of extracurricular programs at the university level (Huang \& Chang, 2004; Kim \& Lee, 2016). On the other hand, it can be seen that more students would be interested and participating in ECA if the university managed the achievement and performance of ECA and implemented a system linking ECA to scholarships. While the grades for the formal curriculum of study are managed by the system, a student's history of participation in ECA is not managed through integration into the curriculum in general. Therefore, in order to activate ECA more effectively and bring about positive educational effects, it is necessary for universities to establish and manage an ECA program that can be integrated with a learning management system so that students can organize and manage their ECA participation.

Second, students who recognized that the ECA system was helpful and easy to use perceived that activities through the ECA system were beneficial to their curriculum learning and participation in ECA, and, in turn, to their career development and college life. It was suggested that students should be able to evaluate the performance of their ECA and record these evaluations in their portfolio as part of their college life achievement (Kuh, 1994; Posner \& Vandell, 1999). As many scholars have suggested (e.g., Shamsudin et al., 2014; Wolf-Wendel et al., 2009), the activation and performance of ECA should be coordinated not only by individual students but also through university or institutional efforts. In order to utilize the 'out-of-class' experiences of students as an educational advantage as Kuh (1994) suggests, clear, coherent, and consistently expressed educational purposes and a guiding institutional philosophy should be the basis. It is also necessary to provide students with ample opportunities to be involved in meaningful out-of-class activities with institutional supports for the systematic assessment of student performance, as well as institutional environments, policies, and practices. In addition, for ECA to operate, an organization and system for managing the ECA program should be established. It is expected that students will be able to participate in ECA programs and improve their educational outcomes if they can establish long-term and systematic planning, history and performance management of their ECA and use these for capacity building and career development during their school years.

Third, the students' perceptions of the helpfulness and usability of the ECA system were found to have an important impact on the students' ECA performance as well as on their curriculum activities. In some studies, participation in ECA has been found to interfere with curriculum learning or to have no relation to the effectiveness of curriculum learning (Huang \& Chang, 2004; Leung, Ng, \& Chan, 2011; Schneider, Kirst, \& Hess, 2003). In order to identify an individual student's abilities and help them improve the required competencies according to their career plan, not only the regular curriculum, but also higher educational results can be achieved when ECA are combined with the regular curriculum (Bakoban \& Aljarallah, 2015; Eccles et al., 2003). In addition, there are a number of studies suggesting that ECA such as club activities and learning communities can help students achieve their learning 
outcomes (Hunt, 2005; Pascarella et al., 2005). These studies support the argument that students should be offered a variety of extracurricular programs at the college level.

Fourth, as a result of examining how well the curriculum and participation in ECA predict students' participation in career development and college life, both the curriculum and the ECA have an important influence on the students' job preparation and college life. These results are based on the rationale and results of previous studies showing that students' participation in various educational and cultural activities and programs in college, and their experience in interpersonal relations have a significant effect on students' academic attitudes and performance and post-graduation performance (Astin, 1984; Kuh, 2003; Pascarella, 1985). Clark, Marsden, Whyatt, Thompson, and Walker (2015) suggest that college students' participation in an ECA program helps them find employment. In particular, students have a more positive tendency to develop their own career when they actively participate in ECA related to their major or subjects (Pascarella et al., 2005). Considering that students express their needs and interest in ECA related to their career and future employment, it is important to provide ECA activities related to students' future careers (Kim \& Lee, 2016).

Participation in ECA programs positively affects students' college life. Satisfaction with college life is the overall feeling of living as part of the college and not just within one's subject area. In particular, the extracurricular realm can serve as the basis of preparations made for the future while satisfying the individuality and diversity needs of students that cannot be completely fulfilled solely by curriculum. In addition, ECA involvement may increase students' sense of engagement or attachment to their school, which in turn can lower school failure and dropout rates (Lamborn, Brown, Mounts, \& Steinberg, 1992; White \& Gager, 2007).

\section{Implication for Research and Practice}

This study is meaningful in that it suggests the direction of extracurricular activities by examining students' perceptions of an ECA system at the university level and reveals that students perceive it as beneficial for their curriculum, ECA, job preparation, and college life. It is necessary to understand how students apply what they have learned through the curriculum to ECA and vice versa. It would also be necessary to conduct qualitative research in order to understand in more detail the extent to which the participation in ECA from the student's perspective is beneficial. Since colleges have recently begun to show interest in establishing extracurricular activity building and management systems, the findings of this study have implications for student affairs practitioners and faculty on how they can use the extracurricular to enhance students' essential learning outcomes.

\section{$7 \quad$ Limitations}

This study has several limitations. First, because students use self-reported data, there is no baseline data on the practical utility and effectiveness of the ECA system. Second, since the data from this study are from one university in South Korea, caution is needed in generalizing the findings of the study.

\section{Conclusion}

Higher education has a responsibility to contribute to society by educating graduates to be creative, well-rounded, and community-oriented. To achieve this goal, universities should provide students with an ample educational environment, the most important of which is the experience of both curriculum and extracurricular activities. Whereas the formal curriculum is under some degree of institutional control, the extracurricular activities are largely defined by students' voluntary participations, which make it difficult to manage the extracurricular activities in a meaningful way or integrate them with the formal curriculum. By providing opportunities for quality extracurricular programs and designing these with educational goals that reflect the formal curriculum, universities may be able to fulfil their obligations for student learning and development. 
Acknowledgments. This work was supported by the sabbatical research grant from Daegu Catholic University in 2017.

\section{References}

1. Ahren, C. (2010). Disentangling the unique effects of co-curricular engagement on self-reported student learning outcomes. (Doctor of Philosophy), Indiana University, Bloomington, IN.

2. Arip, M., \& Yusof, B. (2002). Co-curriculum helps to reduce social problems among adolescence. Co-curricullum: Implication and function, 62-66.

3. Astin, A. W. (1977). Four Critical Years. Effects of College on Beliefs, Attitudes, and Knowledge: Jossey-Bass San Francisco.

4. Astin, A. W. (1984). Student involvement: A developmental theory for higher education. Journal of college student personnel, 25(4), 297-308.

5. Astin, A. W. (1993). What matters in college?: Four critical years revisited (Vol. 1): Jossey-Bass San Francisco.

6. Bae, S. H., \& Kim, H. J. (2012). 대학생의 학습참여 (Student Engagement) 측정 모델의 타당성 검증. [Validation of the National Survey of Student Engagement(NSSE) Model in the Korean context]. 한국교육행정학회 [The Journal of Educational Administration], 30(1), 499-523.

7. Baek, W., \& Jung, H. (2012). 대학생의 비교과 활동(extra-curriculum) 및 전공수업 방식이 학업성취도에 미치는 효과 분석. [An analysis of the effect of the extra-curriculum activities and teaching method on college educational performance]. 한국교육재정경제학회 [The Journal of Economics and Finance of Education], 21(1), 261-283.

8. Bakoban, R., \& Aljarallah, S. (2015). Extracurricular Activities and Their Effect on the Student's Grade Point Average: Statistical Study. Educational Research and Reviews, 10(20), 2737-2744. doi:10.5897/ERR2015.2436.

9. Bartkus, K. R., Nemelka, B., Nemelka, M., \& Gardner, P. (2012). Clarifying the meaning of extracurricular activity: A literature review of definitions. American Journal of Business Education (Online), 5(6), 693.

10.Boone, L. E., Kurtz, D. L., \& Fleenor, C. P. (1988). CEOs: Early signs of a business career. Business Horizons, 31(5), 20-24. doi:10.1016/0007-6813(88)90050-X

11.Camp, W. G. (1990). Participation in Student Activities and Achievement: A Covariance Structural Analysis. The Journal of Educational Research, 83(5), 272-278. doi:10.1080/00220671.1990.10885969

12.Clark, G., Marsden, R., Whyatt, J. D., Thompson, L., \& Walker, M. (2015). 'It's everything else you do...': Alumni views on extracurricular activities and employability. Active Learning in Higher Education, 16(2), 133147. doi:10.1177/1469787415574050

13.Eccles, J. S., \& Barber, B. L. (1999). Student Council, Volunteering, Basketball, or Marching Band. Journal of Adolescent Research, 14(1), 10-43. doi:doi:10.1177/0743558499141003

14.Eccles, J. S., Barber, B. L., Stone, M., \& Hunt, J. (2003). Extracurricular Activities and Adolescent Development. Journal of Social Issues, 59(4), 865-889. doi:10.1046/j.0022-4537.2003.00095.x

15.Foster, C. R. (2007). Extra-curricular activities in the high school: Read Books.

16.Hattie, J. (2008). Visible learning: A synthesis of over 800 meta-analyses relating to achievement: Routledge.

17.Huang, Y.-R., \& Chang, S.-M. (2004). Academic and cocurricular involvement: Their relationship and the best combinations for student growth. Journal of College Student Development, 45(4), 391-406. doi:10.1353/csd.2004.0049

18.Hunt, H. D. (2005). The effect of extracurricular activities in the educational process: influence on academic outcomes? Sociological Spectrum, 25(4), 417-445. doi:10.1080/027321790947171

19.Joseph, N. A. (2009). Exploring the relationship between extracurricular participation and probability of employment for high school graduates. (Master), Georgetown University, Washington, DC.

20.Kim, S., \& Lee, M.-K. (2016). 대학 비교과 프로그램에 대한 학생 인식 및 수요조사를 통한 운영방향성 제고. [A Study on Students' Perceptions and Needs about College Extracurricular Programs]. 학습자중심교과교육학회 [Journal of Learner-Centered Curriculum and Instruction], 16(9), 1-25. doi:10.22251/jlcci.2016.16.9.585

21.Kuh, G. D. (1993). In Their Own Words: What Students Learn Outside the Classroom. American Educational Research Journal, 30(2), 277-304. doi:10.3102/00028312030002277 
22.Kuh, G. D. (1994). Student Learning Outside the Classroom: Transcending Artificial Boundaries. ASHE-ERIC Higher Education Report No. 8.

23.Kuh, G. D. (1995). The other Curriculum. The Journal of Higher Education, 66(2), 123-155. doi:10.1080/00221546.1995.11774770.

24.Kuh, G. D. (2003). What we're learning about student engagement from NSSE: Benchmarks for effective educational practices. Change: The Magazine of Higher Learning, 35(2), 24-32. doi:10.1080/00091380309604090

25.Kuh, G. D., Douglas, K. B., Lund, J. P., \& Ramin-Gyurnek, J. (1994). Student learning outside the classroom: Transcending artificial boundaries (Vol. 8): Graduate School of Education and Human Development, The George Washington University.

26.Kuh, G. D., Hu, S. P., \& Vesper, N. (2000). "They shall be known by what they do": An activities-based typology of college students. Journal of College Student Development, 41(2), 228-244.

27.Kuh, G. D., Kinzie, J., Schuh, J. H., \& Whitt, E. J. (2011). Student success in college: Creating conditions that matter: John Wiley \& Sons.

28.Lamborn, S. D., Brown, B. B., Mounts, N. S., \& Steinberg, L. (1992). Putting school in perspective: The influence of family, peers, extracurricular participation, and part-time work on academic engagement. In F. M. Newmann (Ed.), Student engagement and achievement in American secondary schools (pp. 153-181). New York: Teachers College Press.

29.Leung, C.-H., Ng, C. W. R., \& Chan, P. O. E. (2011). Can Co-Curricular Activities Enhance the Learning Effectiveness of Students?: An Application to the Sub-Degree Students in Hong Kong. International Journal of Teaching and Learning in Higher Education, 23(3), 329-341.

30.Light, R. J. (1990). The Harvard Assessment Seminars: explorations with students and faculty about teaching, learning, and student life: first report, 1990: Harvard University Graduate School of Education.

31.Marsh, H. W. (1992). Extracurricular activities: Beneficial extension of the traditional curriculum or subversion of academic goals? Journal of Educational Psychology, 84(4), 553-562. doi:10.1037/0022-0663.84.4.553

32.Massoni, E. (2011). Positive effects of extra curricular activities on students. ESSAI, 9(1), 27.

33.Moffatt, M. (1989). Coming of age in New Jersey: College and American culture: Rutgers University Press.

34.Moon, S. D., \& Eum, K. S. (2015). 대학에서 비교과영역의 만족요인에 관한 연구. [A Study on the Satisfaction factors in the Extra-Curricula area in College]. 한국경영공학회 [Journal of the Korea Management Engineers Society], 20(1), 147-160.

35.Pascarella, E. T. (1985). Students' Affective Development within the College Environment. The Journal of Higher Education, 56(6), 640-663. doi:10.1080/00221546.1985.11778733

36.Pascarella, E. T., Terenzini, P. T., \& Feldman, K. A. (2005). How college affects students (Vol. 2): Jossey-Bass San Francisco, CA.

37.Posner, J. K., \& Vandell, D. L. (1999). After-school activities and the development of low-income urban children: a longitudinal study. Developmental psychology, 35(3), 868. doi:10.1037/0012-1649.35.3.868

38.Rubin, R. S., Bommer, W. H., \& Baldwin, T. T. (2002). Using extracurricular activity as an indicator of interpersonal skill: Prudent evaluation or recruiting malpractice? Human Resource Management, 41(4), 441-454. doi:10.1002/hrm.10053.

39.Rynes, S. L., Trank, C. Q., Lawson, A. M., \& Ilies, R. (2003). Behavioral coursework in business education: Growing evidence of a legitimacy crisis. Academy of Management Learning \& Education, 2(3), 269-283. doi:10.5465/AMLE.2003.10932135

40.Schneider, B., Kirst, M., \& Hess, F. M. (2003). Strategies for success: High school and beyond. Brookings papers on education policy(6), 55-93.

41.Shamsudin, S., Ismail, S. F., Al-Mamun, A., \& Nordin, S. K. B. S. (2014). Examining the effect of extracurricular activities on academic achievements among the Public University Students in Malaysia. Asian Social Science, 10(9), 171. doi: 10.5539/ass.v10n9p171

42.Stuart, M., Lido, C., Morgan, J., Solomon, L., \& May, S. (2011). The impact of engagement with extracurricular activities on the student experience and graduate outcomes for widening participation populations. Active Learning in Higher Education, 12(3), 203-215. doi:doi:10.1177/1469787411415081

43.Terenzini, P. T., \& Pascarella, E. T. (1991). Twenty years of research on college students: Lessons for future research. Research in Higher Education, 32(1), 83-92. doi:10.1007/bf00992835 
44.Terenzini, P. T., Pascarella, E. T., \& Blimling, G. S. (1996). Students' out-of-class experiences and their influence on learning and cognitive development: A literature review. Journal of College Student Development, $37(2), 149-162$.

45.White, A. M., \& Gager, C. T. (2007). Idle hands and empty pockets? Youth involvement in extracurricular activities, social capital, and economic status. Youth \& Society, 39(1), 75-111. doi:10.1177/0044118X06296906

46.Wolf-Wendel, L., Ward, K., \& Kinzie, J. (2009). A tangled web of terms: The overlap and unique contribution of involvement, engagement, and integration to understanding college student success. Journal of College Student Development, 50(4), 407-428. doi:10.1353/csd.0.0077

47.Wood, J., Little, S., Goldring, L., \& Jenkins, L. (2011). The confidence to do things that I know nothing aboutskills development through extracurricular inquiry activity. Journal of Learning Development in Higher Education, 3, 2-21.

48.Yang, K.-W. (2015). Implementation and Operation of University Extracurricular Education Management and Accreditation System: U-CAAM. Journal of information systems, 24(3), 115-131. doi:10.5859/KAIS.2015.24.3.115 